\title{
Identification of Candida Species from Blood Cultures with Fluorescent In Situ Hybridization (FISH), Polymerase Chain Reaction-Restriction Fragment Length Polymorphism (PCR-RFLP) and Conventional Methods
}

\author{
Kan Kültürü Örneklerinden Candida Türlerinin Floresan In Situ Hibridizasyon (FISH), \\ Polimeraz Zincir Reaksiyonu-Restriksiyon Fragment Uzunluk Polimorfizmi (PCR-RFLP) ve \\ Konvansiyonel Yöntemlerle İdentifikasyonu
}

\author{
Gülay BÖREKÇİ, ${ }^{1}$ Gülden ERSÖZ, ${ }^{2}$ Feza OTAĞ, ${ }^{3}$ Hakan ÖZTURHAN, ${ }^{3}$ Sebahat ŞEN, ${ }^{3}$ \\ Fatma SÖYLEMEZ, ${ }^{4}$ Hilal AKALIN, ${ }^{5}$ Yusuf ÖZKUL, ${ }^{5}$ Gürol EMEKDAŞ ${ }^{3}$
}

\begin{abstract}
${ }^{1}$ Mersin University School of Health; Departments of ${ }^{2}$ Clinical Microbiology and Infectious Diseases, ${ }^{3}$ Medical Microbiology, ${ }^{4}$ Medical Biology, Medical Faculty of Mersin University, Mersin; ${ }^{5}$ Department of Medical Genetics, Medical Faculty of Erciyes University, Kayseri
\end{abstract}

Submitted / Başvuru tarihi: 22.12.2008 Accepted/Kabul tarihi: 13.01.2009

\begin{abstract}
Objectives: Rapid and accurate identification of Candida species from blood cultures is crucial to ensure effective antifungal therapy and to reduce the morbidity and mortality associated with bloodstream fungal infections. In this study, we aimed to identify Candida spp. from blood culture samples with fluorescent in situ hybridization ( $\mathrm{FISH}$ ), polymerase chain reaction-restriction fragment length polymorphism (PCR-RFLP) and conventional methods.
\end{abstract}

Materials and Methods: A total of 50 yeast positive samples out of 325 blood culture positive samples and 50 blood culture negative samples were examined by FISH, PCRRFLP and conventional methods to identify Candida spp.

Results: All three methods generally were compatible for identification of single-species Candida spp. $(p<0.001)$. But, FISH and PCR-RFLP for the identification of multi-species Candida spp. were found more compatible than conventional methods $(p<0.001)$. Besides, FISH is cheaper and quicker than the other two methods in the identification of Candida spp. from blood culture positive samples. The rates of multi-species candidemia with FISH, PCR-RFLP and conventional methods were $20 \%, 6 \%$ and $4 \%$, respectively.

Conclusion: Both PCR-RFLP and FISH methods might be preferred for the rapid identification of Candida spp. from blood culture positive samples. However, FISH is a more suitable method for the detection of multi-species candidemia.

Key words: Candida spp.; FISH; PCR-RFLP; Candidemia; identification.

\begin{abstract}
Amaç: Kan kültürlerinden Candida türlerinin doğru ve hızlı identifikasyonu fungal kan dolaşımı infeksiyonlarla ilgili mortalite ve morbiditeyi azaltmak ve etkili antifungal tedavi sağlamak için önemlidir. Bu çalışmada, kan kültürü örneklerinden Candida türlerinin floresan in situ hibridizasyon (FISH), polimeraz zincir reaksiyonu-restriksiyon fragment uzunluk polimorfizmi (PCR-RFLP) ve konvansiyonel yöntemlerle identifikasyonu amaçlandı.
\end{abstract}

Gereçler ve Yöntemler: Candida türlerininin identifikasyonu için 325 kan kültürü pozitif örnekten maya pozitif olan 50 örnek ile kan kültürü negatif 50 örnek FISH, PCR-RFLP ve konvansiyonel yöntemlerle incelendi

Bulgular: Her üç yöntemde tek tür Candida identifikasyonunda uyumlu idi $(p<0.001)$. Ancak birden fazla Candida türlerinin identifikasyonunda FISH ve PCR-RFLP, konvansiyonel yöntemlere göre daha duyarlı bulundu $(p<0.001)$. Ayrıca, FISH kan kültürü pozitif örneklerden Candida türlerinin identifikasyonunda diğer iki yönteme göre daha hızlı ve ucuzdu. Birden fazla türle oluşan kandidemi oranı FISH, PCR-RFLP ve konvansiyonal yöntemle sırasıyla \%20, \%6 ve $\% 4$ olarak bulundu.

Sonuc: Kan kültürü pozitif örneklerden Candida türlerinin hızlı identifikasyonunda PCR-RFLP ve FISH yöntemi tercih edilebilir. Ancak FISH birden fazla türle oluşan kandidemilerin belirlenmesinde daha uygun bir yöntemdir.

Anahtar sözcükler: Candida spp., FISH, PCR-RFLP, kandidemi, identifikasyon.

Presented at the 13th Turkish Clinical Microbiology and Infectious Diseases Congress, March 14-18, 2007, Antalya, Turkey (13. Türk Klinik Mikrobiyoloji ve Infeksiyon Hastalıkları Kongresi'nde sunulmuştur, 14-18 Mart 2007, Antalya).

Correspondence (iletişim adresi): Dr. Gülay Börekçi. Mersin Üniversitesi Sağlık Yüksekokulu, 33169 Mersin.

Tel: 0324 - 3412815 Fax (Faks): 0324 - 3412315 e-mail (e-posta): gulay_borekci@yahoo.com

() Trakya Üniversitesi Tıp Fakültesi Dergisi. Ekin Tıbbi Yayıncıık tarafından basılımışır. Her hakkı sakııır.

(c) Medical Journal of Trakya University. Published by Ekin Medical Publishing. All rights reserved. 
Identification of Candida Species from Blood Cultures with Fluorescent In Situ Hybridization (FISH),

Polymerase Chain Reaction-Restriction Fragment Length Polymorphism (PCR-RFLP) and Conventional Methods

Candidemia is an important cause of morbidity and mortality in hospitalized patients. ${ }^{[1-3]}$ Candida species are the fourth most commonly isolated organism in bloodstream infections in hospitals. ${ }^{[4,5]}$ Candida albicans is the predominant cause of invasive candidiasis and accounting for over half of all cases in the USA. Candida albicans and other Candida species constitute $70 \%$ to $80 \%$ of invasive bloodstream fungal infections. ${ }^{[2,6]}$ Most Candida species, including Candida albicans, are generally susceptible to systemic antifungal agents, such as fluconazole and amphotericin B. ${ }^{[1,7]}$ In recent years, some studies have reported an increase in candidemia due to non-albicans Candida species, which is the threat of increased mortality and antifungal drug resistance. ${ }^{[7,8]}$ Non-albicans Candida spp. account for $60 \%$ of the episodes of candidemia to be related to the use of antifungal prophylaxis. ${ }^{[1,9]}$

To reduce mortality due to bloodstream fungal infections and to ensure effective antifungal therapy, early detection and identification of Candida species are crucial. Therefore, rapid and accurate methods of identifying Candida spp. in blood cultures are critical. ${ }^{[2,10,11]}$

Current conventional methods for the identification of Candida spp. from positive blood cultures are based on subculture to appropriate fungal medium, including Sabouraud dextrose agar, or CHROMagar Candida medium, and isolated yeast colonies are identified by the phenotypic (germ tube formation, carbohydrate assimilation [e.g., API 20C, ID 32C], and chlamydospore formation on cornmeal agar). However, current methods used on isolated Candida colonies from positive blood culture bottles can take one to three days for identification at the species level. ${ }^{[12]}$

More recently, molecular techniques have found a broad application in the detection and identification of microorganisms in clinical samples without cultivation. ${ }^{[1,13,14]}$ Molecular techniques such as DNA sequence analysis, real-time polymerase chain reaction (RT-PCR), and multiplex PCR have enabled the detection and rapid identification of pathogenic fungi, including Candida species in clinical samples. ${ }^{[14-16]}$ However, most of these tests are still time-consuming and too expensive for routine use.

In recent years, molecular methods with discriminatory power have been required for the accurate, rapid, straightforward and inexpensive identification of Candida at the species level. Various PCR-based methods have been reported for the identification of Candida spp. from clinical samples including whole-blood culture. It has been shown that PCR-restriction fragment length polymorphism (RFLP) is a simple and easy method for medical mycology laboratories to use in the identification of Candida spp. ${ }^{[17,18]}$ Fluorescent in situ hybridization (FISH) with rRNA-targeted oligonucleotide probes has also become a highly valuable tool for the identifi- cation of microorganisms without cultivation. ${ }^{[10,19]}$ This method has been reported to be a reasonable and rapid method in the detection and identification of pathogens. Moreover, this method is cheaper and easier to perform than the other molecular methods in the microbiology laboratory. Pathogenic microorganisms have been detected rapidly and identified from positive blood culture bottles by using FISH. It has been reported that sensitivity and specificity of this test are $100 \%$. ${ }^{[1,20,21]}$ There have been various probes to be used in FISH method such as rRNA-targeted oligonucleotide probes and peptide nucleic acid (PNA) probes. ${ }^{[22,23]}$ Moreover, there has been commercial SeaFast sepsis kit, including yeast to be used for FISH. ${ }^{[24]}$ It has been reported that the sensitivity and specificity of PNA probes and rRNA-targeted oligonucleotide probes were 100\%.[20,21] The commercial kit is also more expensive than others.

The aim of this study was to identify Candida spp. from blood culture positive samples with FISH, PCRRFLP and conventional methods and to compare the practicability, cost, and identification time of three methods.

\section{MATERIALS AND METHODS}

The identification of Candida spp. with conventional methods was performed in the Department of Microbiology, Medical Faculty of Mersin University, PCR-RFLP and FISH analyses were conducted in the Department of Medical Genetics, Medical Faculty of Erciyes University.

\section{Reference Strains}

Candida albicans ATCC 64454, Candida glabrata ATCC 90030, Candida parapsilosis ATCC 90018, Candida tropicalis ATCC 2014 and Candida krusei ATCC 6258 were used as reference strains. In brief, yeast reference strains for FISH were grown in Sabouraud dextrose broth at $35^{\circ} \mathrm{C}$ and harvested while exponential growth phase. The yeast cells were fixed with $4 \%$ paraformaldehyde and then stored at $-20^{\circ} \mathrm{C}$ as previously described. ${ }^{[19]}$ DNA isolation of reference strains were also performed according to the MagNA Pure LC DNA isolation Kit III (Bacteria, Fungi) instructions. Then, RFLP-PCR was applied as mentioned below.

\section{Blood Cultures and Conventional Methods}

$325(13 \%)$ out of a total 2492 blood cultures were positive and Candida spp. was isolated in $50(15.4 \%)$ of 325 consecutive blood culture positive samples between January 2004 and August 2004 at Medical Microbiology laboratory. All the positive blood cultures belonged to different patients and there were not any occurrences of more than one positive blood culture from the same patients. A total of 50 negative blood cultures were also taken in this study. Blood samples from patients with suspected septicemia were spiked into BACTEC 
Identification of Candida Species from Blood Cultures with Fluorescent In Situ Hybridization (FISH),

Polymerase Chain Reaction-Restriction Fragment Length Polymorphism (PCR-RFLP) and Conventional Methods

plus Aerobic/F and BACTEC Peds Plus/F (Becton Dickinson, Sparks, MD, USA) medium and incubated in BACTEC 9050 (BD Diagnostic Systems, UK) blood culture system until the system indicated positive signals. Blood culture suspension was taken aseptically from positive blood culture bottles with a syringe and Gram stain for yeast from positive blood culture bottles was performed. The aliquot of yeast positive blood cultures was divided into three for the identification of Candida spp. with conventional methods, FISH and PCR-RFLP. Two of these blood culture samples taken for FISH and PCR-RFLP were stored at $-20^{\circ} \mathrm{C}$ until use. Another blood culture was inoculated onto Sabouraud dextrose agar (Merck, Germany) and CHROMagar Candida (Becton Dickinson, France) simultaneously for the identification with conventional culture methods. Subsequently, Candida spp. was identified by standard laboratory methods such as germ tube formation, chlamydospore formation on cornmeal agar and API ID 32C (bioMerieux, France) test. Clinically relevant yeasts are conventionally identified by a combination of these phenotypic tests.

\section{FISH}

FISH was performed as previously described. ${ }^{[19,20]}$ An eight-field microscope slide was used for each sample. A total of $5 \mu \mathrm{l}$ from the yeast culture and blood culture samples was directly pipetted to each well onto an eight-field microscope slide and dried for $20 \mathrm{~min}$ at $45^{\circ} \mathrm{C}$. The slides were dehydrated in 50\%, $80 \%$ and $100 \%$ ethanol for 3 min each. In this study, RNAtargeted oligonucleotide probes, including one all yeast probe and four different specific probes, selected for Candida spp. from probeBase website were used. ${ }^{[22]}$ Fluorescein isothiocyanate (FITC) and CY3-labelled oligonucleotide probes were synthesized by Microsynth (Switzerland) and were used PF2 for all yeast (CTC TGG CTT CAC CCT ATT C), Caal for C. albicans (GCC AAG GCT TAT ACT CGC T), Cagl for C. glabrata (CCG CCA AGC CAC AAG GAC T), Cpara for C. parapsilosis (CCT GGT TCG CCA AAA AGG C), Ckrus for C. krusei (GAT TCT CGG CCC CAT GGG) and non Eub for the control probe (ACT CCT ACG GGA GGC AGC). First, the probes for each sample were arranged $C Y 3$ labeledPF2, FITC or CY3 labeled-Caal, CY3 labeled-Cagl, FITC or CY3 labeled-Cpara, and CY3 or FITC labeled non Eub, respectively. Reference strains were used as positive control strain in the study. One microliter universal or specific probe (50 ng), and $9 \mu \mathrm{l}$ hybridization buffer (20\% formamide, $5 \mathrm{M} \mathrm{NaCI}, 1 \mathrm{M}$ Tris $\mathrm{pH}=7,10 \%$ SDS, $\mathrm{H}_{2} \mathrm{O}$ ) were added into each well and incubated in a moist chamber at $46^{\circ} \mathrm{C}$ for $1.5 \mathrm{~h}$. In the mixed samples, $1 \mu$ l Caal (CY3), $1 \mu \mathrm{l}$ Cpara (FITC) probes and $8 \mu \mathrm{l}$ hybridization buffer were applied into same well-slide in the repeated studies. The slides were washed in washing buffer ( $5 \mathrm{M} \mathrm{NaCI}, 1 \mathrm{M}$ Tris $\mathrm{pH}=7,10 \%$ SDS, $\left.\mathrm{H}_{2} \mathrm{O}\right)$ at $46^{\circ} \mathrm{C}$ for $15-20 \mathrm{~min}$ and $10 \mu \mathrm{l}$ of $0.001 \%$ DAPI staining was added to each well. They were then incubated at room temperature for $7 \mathrm{~min}$. After the slides were air-dried, Citifluor (Citifluor Ltd., London) was added onto the slides as a mounting medium. Finally, the slides were examined under a microscope (NIKON E 1000) equipped with a standard filter set and imaging analysis system (Applying Image) using software program (Mac probe Version 4.2.3).

\section{PCR-RFLP}

DNA isolation from Candida reference strains and blood culture samples was performed according to the manufacturer's instructions (MagNA Pure LC DNA isolation kit III; Bacteria, Fungi, Roche, Germany) using the MagNA pure LC system (Roche Diagnostics; Germany). The PCR-RFLP method was applied as described. ${ }^{[18]}$ Fungus-specific universal primer pairs ITS1 (TCC GTA GGT GAA CCT GCG G) and ITS4 (TCC TCC GCT TAT TGA TAT GC) (Molbio, Germany) were applied for PCR. All reactions were performed in a total volume $50 \mu$ l. One microliter of template DNA, forward (ITS1) and reverse (ITS4) primer at $0.2 \mu \mathrm{M}$, deoxynucleocide triphosphate (dNTP) at $0.1 \mathrm{mM}, 5 \mu \mathrm{l}$ of 10X PCR buffer and $2.5 \mathrm{U}$ of Taq DNA polymerase were used for each reaction. The first denaturation step was carried out at $94^{\circ} \mathrm{C}$ for $5 \mathrm{~min}$ and followed by 25 cycles of denaturation at $94^{\circ} \mathrm{C}$ for 30 $\mathrm{s}$, annealing at $56^{\circ} \mathrm{C}$ for $45 \mathrm{~s}$, extension at $72^{\circ} \mathrm{C}$ for $1 \mathrm{~min}$ and final extension at $72^{\circ} \mathrm{C}$ for $7 \mathrm{~min}$. Fifteen microliters of amplified PCR product was analyzed by agarose $2 \%$ gel electrophoresis in TBE buffer stained ethidium bromide $\left(0.5 \mu \mathrm{g} \mathrm{ml}^{-1}\right)$. Re-amplification was applied to negative or slight band samples on gel electrophoresis after first-round amplification. A total of $5 \mu \mathrm{l}$ amplified PCR products were used for re-amplification and the applications stated above were repeated.

MspI enzyme (Fermentas, EU) was used for species level identification of Candida spp. A $10 \mu \mathrm{l}$ aliquot of PCR product with $10 \mathrm{U} \mathrm{MspI}$ in a final reaction volume of 25 $\mu \mathrm{l}$ was incubated at $37^{\circ} \mathrm{C}$ for $2 \mathrm{~h}$. Restriction fragments were analyzed by agarose $3 \%$ gel electrophoresis in TBE buffer at $80 \mathrm{~V}$ for $45 \mathrm{~min}$ and stained with ethidium bromide. The results were evaluated according to the sizes of PCR products for Candida spp. before and after the digestion with MspI enzyme. Sizes of ITS1-ITS4 PCR products were evaluated as 535 bp (297, 238 bp after MspI) for C. albicans, $871 \mathrm{bp}$ (557, $314 \mathrm{bp}$ after MspI) for C. glabrata, 524 bp (340, 184 bp after MspI) for C. tropicalis, 510 bp (261, 249 bp after MspI) for C. krusei, 520 bp (520 bp after MspI) for C. parapsilosis. ${ }^{[18]}$

\section{Statistical Analysis}

Statistical analyses were performed using SPSS software (SPSS 11.5 for Windows). To determine the consistency of FISH, PCR-RFLP and conventional methods for single species and multi-species Candida spp., kappa statistics was used. 


\section{RESULTS}

\section{Identification of Candida spp. from blood culture with conventional methods}

Fifty blood culture negative samples were negative with conventional methods. Fifty yeasts were isolated from positive blood cultures with conventional methods (Table 1). The results of yeasts identified by a combination of the phenotypic tests were similar. Of the 50 yeasts isolated, Candida parapsilosis was identified in 22, Candida albicans in 15, Candida tropicalis in 7, Candida glabrata in 2, C. albicans plus C. parapsilosis in one, Debaryomyces carsonii in one, Kloeckera japonica in one and C. parapsilosis plus Rhodotorula mucilaginosa in one. Two samples detected as C. glabrata and D. carsonii were misidentified in the first isolation. Yet, these samples were identified as $C$. parapsilosis by another person in the second isolation and also confirmed with FISH and PCR-RFLP methods. K. japonica was identified by phenotypic tests such as chlamydospore formation on cornmeal agar, germ tube formation, CHROMagar Candida and API 32, C. Also, D. carsonii and R. mucilaginosa were detected by chlamydospore formation on cornmeal agar, germ tube formation, CHROMagar Candida. Two or more Candida spp. identified from a single set or different sets of blood cultures were considered to have multi-species candidemia. The rate of multi-species candidemia was found to be $4 \%$ ( 2 of 50 positive samples) with culture methods. Of the blood samples identified as Candida spp., 12 samples belonged to internal medicine unit and 11 samples belonged to intensive care unit, and 8 samples to pediatrics unit. Candida parapsilosis was found in most of the blood samples as the main aetiological agent in these three units.

\section{FISH Results}

All yeast probe, Candida specific probes and non-Eub probe were tested by reference strains using FISH method. In the blood samples, only one blood sample identified as K. japonica with conventional methods was not determined with all yeast probe and Candida specific probes because morphological structure of the yeast cell deteriorated and evaluated as negative. Candida spp. was detected in 49 of the $50(98 \%)$ positive blood culture samples with all yeast probe by FISH (Fig. 1) (Table 1).

The 12 C. albicans, 21 C. parapsilosis, one C. glabrata, one $C$. albicans plus $C$. parapsilosis determined with conventional methods were accurately identified by FISH with Candida specific probes. In three samples, C. albicans plus C. parapsilosis was also observed. Candida tropicalis $(n=7)$ was not determined with specific probe because there was no specific probe in the present study. Yet, these samples were confirmed by conventional methods and PCR-RFLP. In 5 of 7 samples identified as $C$. tropicalis with conventional methods, small numbers of C. parapsilosis was also observed. Candida albicans $(\mathrm{n}=3)$, and $C$. parapsilosis $(n=1)$ determined with conventional methods were identified as C. albicans plus C. parapsilosis $(\mathrm{n}=4)$ with FISH. In one blood sample, C. parapsilosis plus R. mucilaginosa were determined with conventional methods, whereas the only C. parapsilosis was identified in this sample with FISH. On the other hand, D. carsonii $(\mathrm{n}=1)$ and $C$. glabrata $(\mathrm{n}=1)$ misidentified with conventional methods were determined as $C$. parapsilosis with FISH. These samples were then confirmed as C. parapsilosis by repeating culture methods. All the samples were negative with non-Eub probe. Also, all the blood culture negative samples were negative with FISH.

In the present study, multi-species candidemia was found in 10 of $50(20 \%)$ blood culture positive samples with FISH. In most of the samples with multi-species candidemia, small numbers of $C$. parapsilosis were observed as the other species. Moreover, especially Cpara probe did not have any similarity to sequences of
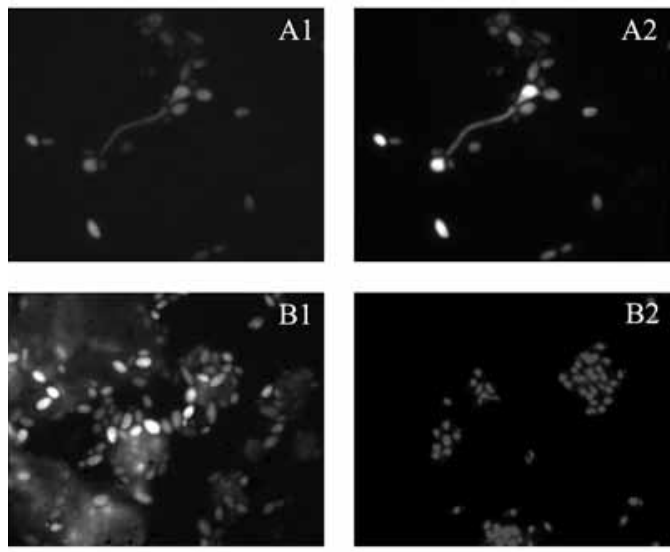
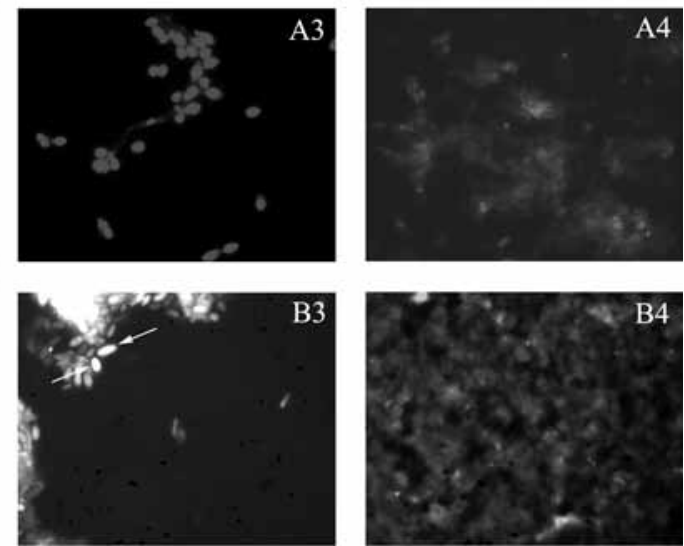

Fig. 1. The images with fluorescence microscopy of Candida albicans and Candida parapsilosis with CY3 and FITClabelled oligonucleotid probes. A. 1. C. albicans with CY3-labelled PF2 probe (red signal; for all yeast), 2. C. albicans with FITC-labelled Caal probe (green signal; specific for C. albicans probe) 3. C. albicans stained with DAPI (blue signal; for DNA). 4. Negative. B. 1. C. parapsilosis with FITC-labelled Cpara probe (green; for C. parapsilosis), 2. C. parapsilosis stained with DAPI (blue signal; for DNA), 3. Mixture of C. albicans with CY3labelled Caal probe (red signal) and C. parapsilosis with FITC-labelled Cpara probe (green signal). 4. Negative. 
Identification of Candida Species from Blood Cultures with Fluorescent In Situ Hybridization (FISH),

Polymerase Chain Reaction-Restriction Fragment Length Polymorphism (PCR-RFLP) and Conventional Methods

Table 1. Results of identification of yeast from positive blood cultures by FISH, PCR-RFLP and conventional methods

\begin{tabular}{|c|c|c|c|}
\hline Sample unit & Conventional methods & $\begin{array}{l}\text { FISH } \\
\text { obe/specific probe) }\end{array}$ & PCR-RFLP \\
\hline 1. Neurosurgery & C. tropicalis & Positive/ND & C. tropicalis \\
\hline 2. Pediatrics unit & C. tropicalis & Positive/ND & Negative \\
\hline 3. Plastic surgery & C. parapsilosis & Positive/C. parapsilosis & C. parapsilosis \\
\hline 4. Internal medicine & C. albicans & Positive/C. albicans & C. albicans \\
\hline 5. Pediatrics unit & C. albicans & Positive/C. albicans & C. albicans \\
\hline 6. Intensive care & C. albicans & Positive/C. albicans & C. albicans \\
\hline 7. Internal medicine & C. parapsilosis & Positive/C. parapsilosis & C. parapsilosis \\
\hline 8. Internal medicine & C. albicans & Positive/C. albicans & C. albicans \\
\hline 9. Internal medicine & C. parapsilosis & Positive/C. parapsilosis & C. parapsilosis \\
\hline 10. Intensive care & C. tropicalis & Positive/C. parapsilosis $\mathrm{d}+\mathrm{ND}$ & C. tropicalis + C. parapsilosis \\
\hline 11. Internal medicine & C. glabrata $\mathrm{a} / \mathrm{C}$. parapsilosis $\mathrm{b}$ & Positive/C. parapsilosis & C. parapsilosis \\
\hline 12. Neurology & C. parapsilosis & Positive/C. parapsilosis & C. parapsilosis \\
\hline 13. Plastic surgery & C. parapsilosis & Positive/C. parapsilosis & C. parapsilosis \\
\hline 14. Urology & C. albicans & Positive/C. albicans & C. albicans \\
\hline 15. General surgery & C. parapsilosis & Positive/C. parapsilosis & C. parapsilosis \\
\hline 16. Pediatrics unit & C. albicans & Positive/C. albicans $+C$. parapsilosis $\mathrm{d}$ & C. albicans \\
\hline 17. Chest diseases & C. parapsilosis & Positive/C. parapsilosis & C. parapsilosis \\
\hline 18. Internal medicine & C. parapsilosis & Positive/C. parapsilosis & C. parapsilosis \\
\hline 19. Pediatrics unit & C. albicans & Positive/C. albicans $+C$. parapsilosis $\mathrm{d}$ & C. albicans \\
\hline 20. Internal medicine & C. albicans & Positive/C. albicans $+C$. parapsilosis $\mathrm{d}$ & C. albicans \\
\hline 21. Internal medicine & C. parapsilosis & Positive/C. parapsilosis & C. parapsilosis \\
\hline 22. Neurology & Kloeckera japonica & Negative & C. tropicalis \\
\hline 23. Internal medicine & C. albicans & Positive/C. albicans & C. albicans \\
\hline 24. Pediatrics unit & C. tropicalis & Positive/C. parapsilosis $\mathrm{d}+\mathrm{ND}$ & C. tropicalis + C. parapsilosis \\
\hline 25. Pediatrics unit & C. parapsilosis & Positive/C. parapsilosis & C. parapsilosis \\
\hline 26. Intensive care & C. parapsilosis & Positive/C. parapsilosis & C. parapsilosis \\
\hline 27. Neurology & C. tropicalis & Positive/C. parapsilosis $\mathrm{d}+\mathrm{ND}$ & C. tropicalis $+C$. parapsilosis \\
\hline 28. General surgery & D. carsonii a/C. parapsilosis b & Positive/C. parapsilosis & C. parapsilosis \\
\hline 29. Thoracic Surgery & C. albicans & Positive/C. albicans & C. albicans \\
\hline 30. Neurosurgery & C. albicans & Positive/C. albicans & C. albicans \\
\hline 31. Infectious diseases & C. tropicalis & Positive/C. parapsilosis $\mathrm{d}+\mathrm{ND}$ & C. tropicalis \\
\hline 32. Neurology & C. tropicalis & Positive/C. parapsilosis $\mathrm{d}+\mathrm{ND}$ & C. tropicalis \\
\hline 33. Plastic surgery & C. parapsilosis & Positive/C. parapsilosis & C. parapsilosis \\
\hline 34. Dermatology & C. albicans & Positive/C.albicans & C. albicans \\
\hline 35. Pediatrics unit & C. parapsilosis & Positive/C. parapsilosis & C. parapsilosis \\
\hline 36. Internal medicine & C. parapsilosis & Positive/C. parapsilosis & C. parapsilosis \\
\hline 37. Pediatrics unit & C. parapsilosis & Positive/C. parapsilosis & C. parapsilosis \\
\hline 38. Intensive care & C. albicans $+C$. parapsilosis & Positive/C. albicans + C. parapsilosis & C. parapsilosis \\
\hline 39. Neurology & C. parapsilosis & Positive/C. parapsilosis & C. parapsilosis \\
\hline 40. Cardiovascular surgery & C. parapsilosis & Positive/C. parapsilosis & C. parapsilosis \\
\hline 41. Intensive care & C. parapsilosis & Positive/C. parapsilosis & C. parapsilosis \\
\hline 42. Urology & C. albicans & Positive/C. albicans & C. albicans \\
\hline 43. Neurosurgery & C. parapsilosis & Positive/C. parapsilosis & C. parapsilosis \\
\hline 44. Intensive care & C. albicans & Positive/C. albicans & C. albicans \\
\hline 45. Intensive care & C. parapsilosis & Positive/C. albicans $\mathrm{d}+$ C. parapsilosis & C. parapsilosis \\
\hline 46. Intensive care & C. parapsilosis & Positive/C. parapsilosis & C. parapsilosis \\
\hline 47. Cardiovascular surgery & C. parapsilosis $+R$. mucilaginosa & Positive/C. parapsilosis & C. parapsilosis \\
\hline 48. Internal medicine & C. glabrata & Positive/C. glabrata & C. glabrata \\
\hline 49. Intensive care & C. albicans & Positive/C. albicans & C. albicans \\
\hline 50. Intensive care & C. parapsilosis & Positive/C. parapsilosis & C. parapsilosis \\
\hline
\end{tabular}

ND: Not determined (because we did not use any probe for C. tropicalis in this study); a: Wrong interpretation in the first culture; b: Correct interpretation in the second culture. c: This sample was not determined because of morphological structure of the yeast cell deteriorated; d: Small numbers of second Candida species in mixed samples were observed. 
Identification of Candida Species from Blood Cultures with Fluorescent In Situ Hybridization (FISH),

Polymerase Chain Reaction-Restriction Fragment Length Polymorphism (PCR-RFLP) and Conventional Methods

Table 2. The consistency of FISH, PCR-RFLP and conventional methods for single species and multispecies Candida spp.

\begin{tabular}{|c|c|c|c|c|c|}
\hline Candida spp. & Positive $(\%)$ & Kappa value & $p$ & Consistency & Results \\
\hline \multicolumn{6}{|l|}{ Candida albicans } \\
\hline Conventional methods - FISH & $15(100)$ & 0.926 & $<0.001$ & Yes & Excellent \\
\hline Conventional methods - PCR & $14(93.3)$ & 0.922 & $<0.001$ & Yes & Excellent \\
\hline FISH-PCR & $15(100)$ & 0.926 & $<0.001$ & Yes & Excellent \\
\hline \multicolumn{6}{|l|}{ Candida parapsilosis } \\
\hline Conventional methods - FISH & $24(100)$ & 0.760 & $<0.001$ & Yes & Good \\
\hline Conventional methods - PCR & $24(100)$ & 0.872 & $<0.001$ & Yes & Excellent \\
\hline FISH-PCR & $29(85.3)$ & 0.884 & $<0.001$ & Yes & Excellent \\
\hline \multicolumn{6}{|l|}{ Candida tropicalis } \\
\hline Conventional methods - PCR & $5(71.4)$ & 0.823 & $<0.001$ & Yes & Excellent \\
\hline \multicolumn{6}{|l|}{ Candida glabrata } \\
\hline Conventional methods - FISH & $1(50)$ & 0.662 & $<0.001$ & Yes & Good \\
\hline Conventional methods - PCR & $1(50)$ & 0.662 & $<0.001$ & Yes & Good \\
\hline FISH-PCR & $1(100)$ & 1.000 & $<0.001$ & Yes & Excellent \\
\hline \multicolumn{6}{|l|}{ Multi-species } \\
\hline Conventional methods - FISH & $1(50)$ & 0.138 & $>0.001$ & No & - \\
\hline Conventional methods - PCR & $0(0)$ & -0.25 & $>0.001$ & No & - \\
\hline FISH-PCR & $3(30)$ & 0.435 & $<0.001$ & Yes & Medium \\
\hline
\end{tabular}

other fungal species. Three of 10 mix cultures detected with FISH were identified with PCR-RFLP method and also one of these was determined accurately with conventional methods.

\section{PCR-RFLP Results}

Twenty eight $(56 \%)$ out of 50 positive blood culture samples were successfully analyzed after the firstround amplification. After re-amplification, only one sample was negative. In 22 C. parapsilosis, 12 C. albicans, one C. glabrata, and one C. albicans plus C. parapsilosis determined with conventional methods were accurately identified with PCR-RFLP. In one blood sample, $C$. parapsilosis plus $R$. mucilaginosa were determined with conventional methods, whereas only C. parapsilosis was identified in this sample with PCR-RFLP methods. In 3 of 7 blood samples, C. tropicalis was identified with both conventional methods and PCR-RFLP. In 3 of 7 C. tropicalis isolates, C. tropicalis plus C. parapsilosis were identified with PCR-RFLP. In one blood sample, $C$. tropicalis, which had been identified as K. japonica with conventional methods, was determined with PCR-RFLP. Debaryomyces carsoni $(\mathrm{n}=1)$ and C. glabrata $(\mathrm{n}=1)$ misidentified with conventional methods were $C$. parapsilosis with PCR-RFLP (Table 1). Fifty blood culture negative samples were also negative with PCR-RFLP. With this method, multi-species candidemia was found in 3 of 50 (6\%) blood culture positive samples.

\section{The comparison of FISH with PCR-RFLP and conventional culture methods}

In the present study, of the 50 samples, the two blood samples misidentified as D. carsonii and C. glabrata in the first culture were then identified correctly with FISH, PCR-RFLP and in a second culture as C. parapsilosis. In one blood sample, C. tropicalis, which had been determined positive with culture methods, was found to be negative with PCR-RFLP. In one blood sample, $C$. parapsilosis plus $R$. mucilaginosa were determined with conventional methods, whereas only C. parapsilosis was identified in this sample with both FISH and PCR-RFLP methods. Only one sample was evaluated as negative with FISH because morphological structure of the yeast cell deteriorated. Initially, in $22(44 \%)$ out of 50 positive blood culture samples were not obtained DNA with MagNA Pure LC DNA isolation kit in PCR-RFLP. Fifty $(100 \%)$ out of 50 blood culture negative samples were also found negative with conventional methods, FISH and RFLP-PCR. The consistency of three methods is showed in Table 2. All three methods were compatible

Table 3. Comparison of FISH with PCR-RFLP and conventional methods

\begin{tabular}{lccc}
\hline Methods & Time & Cost per sample & Multi-species candidemia (\%) \\
\hline FISH & $2.5 \mathrm{~h}$ & $9.1 \$$ & 20 \\
PCR-RFLP & $6-8 \mathrm{~h}$ & $33.8 \$$ & 6 \\
Conventional methods & $1-3$ days & $16.9 \$$ & 4 \\
\hline
\end{tabular}


Identification of Candida Species from Blood Cultures with Fluorescent In Situ Hybridization (FISH), Polymerase Chain Reaction-Restriction Fragment Length Polymorphism (PCR-RFLP) and Conventional Methods

for single species Candida spp. (Candida glabrata, Candida parapsilosis, Candida albicans) $(\mathrm{p}<0.001)$. The consistency of FISH for Candida tropicalis was not evaluated because there was not specific probe while PCR-RFLP and conventional methods for Candida tropicalis were compatible $(\mathrm{p}<0.001)$. FISH and PCR-RFLP for multi-species Candida spp. were found compatible $(\mathrm{p}<0.001)$.

In addition, the period of identification by FISH was also very short and the cost per sample was lower in FISH. The cost per sample for FISH, PCR-RFLP and conventional methods were 9.1 \$, 33.8 \$ and 16.9\$, respectively. Multi-species candidemia was also observed to be higher with FISH than the other two methods (Table 3).

\section{DISCUSSION}

Although several molecular-based methods have been developed for the identification of Candida spp., recently, new molecular approaches for the diagnosis of fungal infections have been asserted that are straightforward, rapid to apply, and are inexpensive in routine laboratories. These tests are required for the identification of Candida spp., which is essential in order to reduce morbidity and mortality, and for the treatment of patients suffering from systemic candidiasis. ${ }^{[10,18,25]}$

In the present study, the identification of Candida spp. from blood samples of patients with systemic candidiasis was performed with three different methods. The identification of Candida spp. with conventional methods takes at least 1-3 days, and sometimes it may lead to misinterpretation of the results. In this study, two blood samples were misidentified with conventional methods. Furthermore, experienced personnel are essential in the evaluation of the microscopic and culture.

Using one restriction enzyme with PCR-RFLP method allows the identification of six medically important Candida spp. It was applied by Mirhendi et al. ${ }^{[18]}$ using only one enzyme for the identification of six Candida spp. in 137 clinical isolates. However, MspI enzyme did not discriminate the species level of C. albicans and C. dubliniensis because the digestion of $C$. albicans and C. dubliniensis with MspI enzyme had similar patterns. Mirhendi et al. ${ }^{[17]}$ used BInI enzyme in their studies to discriminate these two Candida species. In the present study, BInI enzyme was not used to discriminate $C$. dubliniensis in the samples identified as $C$. albicans with PCR-RFLP because these samples were confirmed with both FISH and conventional methods. We found that PCR-RFLP was compatible with both FISH and conventional methods, except multi-species candidemia. Although PCR-based methods are also highly sensitive, it may be associated with several problems. An interlaboratory study involving 30 laboratories in 18 countries to estimate the performance of amplification tests for routine diagnosis has reported that only five laboratories correctly identified the presence or absence of DNA. ${ }^{[26]}$ In this study, $56 \%$ of blood culture positive sam- ples could be successfully analyzed in the first-round amplification with RFLP-PCR. The failure in first-round amplification may have three reasons: storage and transport of samples, inhibitors in blood and the presence of a small amount of the DNA in the sample. Van Deventer et al. ${ }^{[27]}$ demonstrated that storage conditions of blood samples influence sensitivity and reproducibility of the PCR assays, although they could not clarify the negative effect of freezing on PCR detection, since under microscopy the Candida cells looked intact and were still viable when checked by culture. Wolff et al. ${ }^{[28]}$ showed that the PCR reactions were completely inhibited by hemoglobin of $0.1 \mathrm{mg} / \mathrm{ml}$ and by a heparin concentration of $1.3 \times 10-$ $3 \mathrm{mg} / \mathrm{ml}$. Moreover, sodium polyanetholesulfonate, which is ingredient of blood culture broth for neutralization of antibiotics, also appeared to represent a potent inhibitor in PCR techniques. ${ }^{[29]}$ Nucleic acid amplification assays might therefore be affected by inhibitors and can cause false-negative results. Yet, it has been determined that there was no inhibition of PCR with MagNA Pure LC DNA isolation kit III (Bacteria, Fungi) which is used in this study. ${ }^{[30]}$ We thought that the small amount of the DNA in the samples might be affected from the storage and transport conditions or a small amount of DNA in the samples were not isolated with MagNA Pure LC DNA isolation kit III (Bacteria, Fungi). That there is an increase in the positive, after second- round amplification supported this view.

Many studies have shown that FISH has a very high sensitivity and specificity for the identification of microorganism. ${ }^{[11,20,21]}$ It has also been determined that PNA FISH test for C. albicans is more accurate than standard culture methods and results in significant cost saving. ${ }^{[31]}$ Our results showed that FISH was compatible with PCRRFLP and conventional methods, except multi-species candidemia. FISH and PCR-RFLP were found compatible in the detection of multi-species candidemia. In this study, only one sample was evaluated as negative with FISH. Negative sample determined by FISH may be affected from prolonged storage. Prolonged storage may have decreased the sensitivity of FISH because long time storage of fixed cells is not recommended. ${ }^{[19]}$ Moreover, FISH was better than the other two methods regarding the identification time and the cost.

Molecular methods (FISH, seminested PCR) are more sensitive in the detection of multi-species candidemia than conventional culture methods. ${ }^{[32,33]}$ Haase et al. ${ }^{[33]}$ and Perry-O'Keefe et al. ${ }^{[34]}$ have shown that mixtures of isolates in cultures can be detected by FISH method and it has been indicated that PNA-FISH is more sensitive than conventional methods in the detection of mixtures of isolates in blood cultures. ${ }^{[33,34]}$ Similarly, the rate of multi-species candidemia with FISH is higher than PCR-RFLP and conventional methods in the present study. With FISH, the rate of multi-species candidemia was 3.4 times higher than that of PCR-RFLP, and about 
Identification of Candida Species from Blood Cultures with Fluorescent In Situ Hybridization (FISH),

Polymerase Chain Reaction-Restriction Fragment Length Polymorphism (PCR-RFLP) and Conventional Methods

10.2 times higher than that of conventional methods. The rate of multi-species candidemia with PCR-RFLP has not been found similar to that of FISH, which might be caused by the difficulty in obtaining DNA from cells. However, both FISH and PCR-RFLP were more compatible in the detection of multi-species candidemia than conventional methods in this study. Unfortunately, we could not make sequence analysis to confirm of these results. We thought that the reason for high rate of multispecies candidemia may be due to catheter-related nosocomial infections because all patients had catheter (not shown data). However, if clinical features of patients with multi-species candidemia are investigated, it may help to clean up the multi-species cases.

Although a chromogenic agar (CHROMagar Candida) was used to detect multi-species candidemia it was found that the rate of multi-species candidemia with conventional methods was low than FISH in the present study. There may be two reasons for the discrepancy with FISH and Chromagar Candida medium in mixed cultures. First, second species in mixed cultures may be not grown in the medium. Some studies have shown that microorganisms are not able to grow on medium while they are presence in microscopy. ${ }^{[35,36]}$ Second reason is that mixtures of similar-appearing yeast isolates could have been missed. Hospenthal et al. ${ }^{[37]}$ have determined that some Candida spp. can be hampered in mixtures of yeast isolates that produce pink colonies. Molecular methods appears more reliable to detect mixture isolates than phenotyping methods, especially FISH.

Our study has some limitations. First, the number of cases with candidemia was small. Another limitation was that there was no C. tropicalis-specific probe for FISH in this study. Yet, this limitation did not affect the results because all blood samples were definitely confirmed with all yeast probe, PCR-RFLP and conventional methods.

In conclusion, both FISH and PCR-RFLP methods are efficient methods to rapidly identify Candida spp. from blood culture positive samples in routine laboratories. PCR-RFLP method is simple and practical. FISH might also be preferred to the other two methods for routine applications in mycology laboratories; because FISH has advantages in terms of being practical, easy, cheap and quick. Moreover, this method appears to be more suitable, especially in the detection of multi-species candidemia.

\section{Acknowledgement}

This study was supported by Scientific Research Projects Unit, Mersin University, Turkey (Project no. BAP-TF TTB (GE) 2004-3). We thank Prof. Dr. A. Nedret Koç at the Department of Microbiology, Erciyes University, Kayseri, Turkey and MSc. Semra Erdoğan at the Department of Biostatistics, Mersin University, Mersin, Turkey for their help.

\section{REFERENCES}

1. Bedini A, Venturelli C, Mussini C, Guaraldi G, Codeluppi $\mathrm{M}$, Borghi V, et al. Epidemiology of candidaemia and antifungal susceptibility patterns in an Italian tertiary-care hospital. Clin Microbiol Infect 2006;12:75-80.

2. Pfaller MA, Diekema DJ. Epidemiology of invasive candidiasis: a persistent public health problem. Clin Microbiol Rev 2007;20:133-63.

3. Yamamura DL, Rotstein C, Nicolle LE, Ioannou S. Candidemia at selected Canadian sites: results from the Fungal Disease Registry, 1992-1994. Fungal Disease Registry of the Canadian Infectious Disease Society. CMAJ 1999;160:493-9.

4. Edmond MB, Wallace SE, McClish DK, Pfaller MA, Jones RN, Wenzel RP. Nosocomial bloodstream infections in United States hospitals: a three-year analysis. Clin Infect Dis 1999;29:239-44.

5. Wisplinghoff $\mathrm{H}$, Bischoff $\mathrm{T}$, Tallent SM, Seifert $\mathrm{H}$, Wenzel $\mathrm{RP}$, Edmond MB. Nosocomial bloodstream infections in US hospitals: analysis of 24,179 cases from a prospective nationwide surveillance study. Clin Infect Dis 2004;39:309-17.

6. Pfaller MA, Diekema DJ, Jones RN, Sader HS, Fluit AC, Hollis RJ, et al. International surveillance of bloodstream infections due to Candida species: frequency of occurrence and in vitro susceptibilities to fluconazole, ravuconazole, and voriconazole of isolates collected from 1997 through 1999 in the SENTRY antimicrobial surveillance program. J Clin Microbiol 2001;39:3254-9.

7. Bassetti M, Righi E, Costa A, Fasce R, Molinari MP, Rosso R, et al. Epidemiological trends in nosocomial candidemia in intensive care. BMC Infect Dis 2006;6:21.

8. Hope W, Morton A, Eisen DP. Increase in prevalence of nosocomial non-Candida albicans candidaemia and the association of Candida krusei with fluconazole use. J Hosp Infect 2002;50:56-65.

9. Clancy CJ, Staley B, Nguyen MH. In vitro susceptibility of breakthrough Candida bloodstream isolates correlates with daily and cumulative doses of fluconazole. Antimicrob Agents Chemother 2006;50:3496-8.

10. Kempf VA, Mändle T, Schumacher U, Schäfer A, Autenrieth IB. Rapid detection and identification of pathogens in blood cultures by fluorescence in situ hybridization and flow cytometry. Int J Med Microbiol 2005;295:47-55.

11. Rigby S, Procop GW, Haase G, Wilson D, Hall G, Kurtzman $\mathrm{C}$, et al. Fluorescence in situ hybridization with peptide nucleic acid probes for rapid identification of Candida albicans directly from blood culture bottles. J Clin Microbiol 2002;40:2182-6.

12. Mycology. In: Forbes BA, Sahm DF, Weissfeld AS, editors. Bailey and Scott's diagnostic microbiology. 10th ed. St. Louis: Mosby; 1998. p. 870-961.

13. Bautista-Muñoz C, Boldo XM, Villa-Tanaca L, HernándezRodríguez C. Identification of Candida spp. by randomly amplified polymorphic DNA analysis and differentiation between Candida albicans and Candida dubliniensis by direct PCR methods. J Clin Microbiol 2003;41:414-20.

14. Maaroufi Y, Heymans C, De Bruyne JM, Duchateau V, Rodriguez-Villalobos H, Aoun M, et al. Rapid detection of Candida albicans in clinical blood samples by using a TaqMan-based PCR assay. J Clin Microbiol 2003;41:3293-8.

15. Chang HC, Leaw SN, Huang AH, Wu TL, Chang TC. Rapid identification of yeasts in positive blood cultures by a multiplex PCR method. J Clin Microbiol 2001;39:3466-71.

16. Leaw SN, Chang HC, Sun HF, Barton R, Bouchara JP, Chang 
Identification of Candida Species from Blood Cultures with Fluorescent In Situ Hybridization (FISH),

Polymerase Chain Reaction-Restriction Fragment Length Polymorphism (PCR-RFLP) and Conventional Methods

TC. Identification of medically important yeast species by sequence analysis of the internal transcribed spacer regions. J Clin Microbiol 2006;44:693-9.

17. Mirhendi H, Makimura K, Zomorodian K, Maeda N, Ohshima T, Yamaguchi H. Differentiation of Candida albicans and Candida dubliniensis using a single-enzyme PCRRFLP method. Jpn J Infect Dis 2005;58:235-7.

18. Mirhendi H, Makimura K, Khoramizadeh M, Yamaguchi H. A one-enzyme PCR-RFLP assay for identification of six medically important Candida species. Jpn J Med Mycol 2006;47:225-9.

19. Amann RI. In situ identification of microorganisms by whole cell hybridization with rRNA-targeted nucleic acid probes. In: Akkermans ADL, Van Elsas JD, De Bruijn FJ, editors. Molecular microbial ecology manual. Dordrecht: Kluwer Academic Publishers; 1995. p. 1-15.

20. Kempf VA, Trebesius K, Autenrieth IB. Fluorescent in situ hybridization allows rapid identification of microorganisms in blood cultures. J Clin Microbiol 2000;38:830-8.

21. Oliveira K, Haase G, Kurtzman C, Hyldig-Nielsen JJ, Stender H. Differentiation of Candida albicans and Candida dubliniensis by fluorescent in situ hybridization with peptide nucleic acid probes. J Clin Microbiol 2001;39:4138-41.

22. probeBase. Available from: http:/ / www.microbial-ecology. net/probebase/

23. PNA FISH. Available from: http://www.advandx.com/ products/pna_fish.php.

24. BACTfish. Available from: http://www.bactfish.com/ product_range/diagnostic_kits/sepsis_kit/sepsis_kit.html

25. Terlecka JA, du Cros PA, Orla Morrissey C, Spelman D. Rapid differentiation of Candida albicans from non-albicans species by germ tube test directly from BacTAlert blood culture bottles. Mycoses 2007;50:48-51.

26. Noordhoek GT, van Embden JD, Kolk AH. Reliability of nucleic acid amplification for detection of Mycobacterium tuberculosis: an international collaborative quality control study among 30 laboratories. J Clin Microbiol 1996;34:2522-5.

27. van Deventer AJ, Goessens WH, van Belkum A, van Vliet HJ, van Etten EW, Verbrugh HA. Improved detection of Candida albicans by PCR in blood of neutropenic mice with systemic candidiasis. J Clin Microbiol 1995;33:625-8.

28. Wolff A, Perch-Nielsen IR, Poulsen CR, El-Ali J, Bang DD. Removal of PCR inhibitors using dielectrophoresis for sample preparation in a microfabricated system. 7th International Conference on Miniaturized Chemical and
Biochemical Analysis Systems. October 5-9 2003; Squaw Valley, California USA: 1137-40.

29. Fredricks DN, Relman DA. Improved amplification of microbial DNA from blood cultures by removal of the PCR inhibitor sodium polyanetholesulfonate. J Clin Microbiol 1998;36:2810-6.

30. Kirchgesser M, Alberdi MB, Bollwein M, Miedl B, Malmberg W, Reischl U. MagNA pure LC DNA isolation kit III (bacteria, fungi)-automated isolation of bacterial DNA from various sample materials. Biochemica 2001;4:4-6. Available from: http://www. Roche-applied-science.com/PROD_ INF/BIOCHEMI/no4_01/PDF/p4_6.pdf. 23.06.2008.

31. Mankes K, Forrest G, Jabra-Rizk MA, Johnson JK, Venezia RA. Outcomes of peptide nucleic acid fluorescence in situ hybridization probes for rapid identification of Candida albicans. [Abstract 276]. 43rd Annual Meeting of IDSA, October 6-9, 2005. San Francisco, USA. Available from: http:/ / www. advandx.com / uploads / documents / idsa2005candidapnauniversityofmarylandmedicalcenter.pdf.

32. Ahmad S, Khan Z, Mustafa AS, Khan ZU. Seminested PCR for diagnosis of candidemia: comparison with culture, antigen detection, and biochemical methods for species identification. J Clin Microbiol 2002;40:2483-9.

33. Haase G, Peltroche-Llacsahuang H, Chapin K, Castellone $\mathrm{T}$, Oliveira K, Stender H, et al. Evaluation of dual color S. aureus/CNS PNA FISH for simultaneous identification of Staphylococcus aureus and coagulase-negative Staphylococci directly from positive blood culture bottles. ASM 2006;P.C-059. Available from: http://www.advandx. com/uploads/documents/asm2006postersacnsfinal.pdf.

34. Perry-O'Keefe H, Rigby S, Oliveira K, Sørensen D, Stender $\mathrm{H}$, Coull J, et al. Identification of indicator microorganisms using a standardized PNA FISH method. J Microbiol Methods 2001;47:281-92.

35. Sonnex C, Lefort W. Microscopic features of vaginal candidiasis and their relation to symptomatology. Sex Transm Infect 1999;75:417-9.

36. Linhares LM, Witkin SS, Miranda SD, Fonseca AM, Pinotti JA, Ledger WJ. Differentiation between women with vulvovaginal symptoms who are positive or negative for Candida species by culture. Infect Dis Obstet Gynecol 2001;9:221-5.

37. Hospenthal DR, Murray CK, Beckius ML, Green JA, Dooley DP. Persistence of pigment production by yeast isolates grown on CHROMagar Candida medium. J Clin Microbiol 2002;40:4768-70. 